Vol. 7, No. 1, 2020

https://doi.org/10.23939/eem2020.01.025

UDC 331.556.4 : 331.215.1

JEL Classification Code J21, J40, C30

\author{
S. Lykholat \\ Lviv Polytechnic National University, Ukraine, Associate Professor \\ e-mail: s1925p@i.ua \\ ORCID: 0000-0002-0517-6852
}

\begin{abstract}
O. Mulska
State Institution "Institute of regional research named after M.I. Dolishniy of NAS of Ukraine", Ukraine, researcher e-mail: oliochka.mulska@gmail.com ORCID: 0000-0002-1666-3971

\author{
Ternopil Ivan Puluj National Technical University, Ukraine, Associate Professor \\ E-mail: kaf_mv@tu.edu.te.ua \\ ORCID: 0000-0002-1400-9503
}

N. Rozhko
\end{abstract}

\title{
LABOUR MARKET OF UKRAINE IN THE CONDITIONS OF INTENSIFICATION OF MIGRATION POPULATION PROCESSES
}

\begin{abstract}
The article identifies that the labour market is a complex integrated system with a large number of economic entities, including intermediaries or immigrants, as well as socio-economic processes, ambiguous determinants, large amounts of information and ever-increasing links between market contractors. The impact of population migration on the labour market in Ukraine is analysed, as well as the socioeconomic factors on which the level of balancing of the labour market depends, with the adjustment of labour supply to the volume of emigration of the population are outlined. It is substantiated that the balance in the labour market can be achieved in the implementation of strategic partnership between the state, employers and institutions of the vocational education system, taking into account the socio-economic factors influencing the aggregate demand and aggregate supply in the labour market. It is proved that the structural characteristics of the labour market determine the migration intentions of the population, and the impact of the labour market conditions on emigration should be considered in the context of direct and inverse relations with the main macroeconomic and demographic processes. The research used general scientific methods of cognition
\end{abstract}

(both empirical and theoretical), which are provided with specific tools for the subject area of knowledge, including factor and Ex-post analyses, and multivariate regression modelling. Based on the econometric study, the model of the relationship between the real level of remuneration in the donor and host country and the index (level) of balancing the labour market according to the adjusted aggregate supply (for the relevant population emigration) are presented for the first time.

Key words: labour market, migration, intensification, labour market balancing level, vacant demand, aggregate supply, current demand.

Formulation of the problem. Structural changes occurring in the Ukrainian economy at the present stage of development lead to significant negative changes in the labour market. They are to increase the scale of general and long-term unemployment and, as a consequence, inefficient use of the labour potential of the population, reduce the number of economically active population both in the country as a whole and in individual regions. The problem of introducing active measures to 


\section{S. Lykholat, O. Mulska, N. Rozhko}

prevent long-term unemployment is of particular relevance in the conditions where Ukraine has a very difficult and tense situation in terms of balancing supply and demand in the labour market. The lack of real prospects for reducing labour migration and job creation leads to an even greater imbalance in national labour market.

The volume of labour migration in Ukraine is increasing every year, and after the introduction of a visa-free regime and the opening of internal labour markets for foreign workers in Ukraine by individual EU Member States, new opportunities have emerged in the international labour market. Thus, most of the labour force emigrated to Poland, Germany, Italy and Spain, where wages and social security are much higher than in Ukraine. Migration processes affect the national labour market: on the one hand, emigration reduces unemployment in the country and, on the other, causes a shortage of labour in certain professions and thus significantly affects the level of wages. These processes have been observed for several decades, which is why the study of balancing the labour market in Ukraine in the context of increased migration activity of the population is especially relevant.

The state of labour market is the priority socio-economic parameter affecting the social development and competitiveness of the national economy.

On the one hand, the labour market is an element of the economic system on which the vector and the pace of macroeconomic dynamics of the country depend, and on the other, the market mediates the impact of macroeconomic policy and development on the well-being of the population and the state of many social processes [1, p. 31]. Scholars of Lviv School of Regional Studies say that labour market is a system in which the labour market and the job market organically interact [2, p. 22]. O.Levytska made an amendment that the conditions of functioning and balancing of the labour market are also influenced by nontraditional forms of employment, increasing the number of "precariat" as a separate social class, increasing requirements for the quality of human capital and the need to invest in its development [3]. Therefore, it should be argued that the main categories that characterize the efficiency of the functioning of the labour market are economically active population, economically inactive population, unemployed, employed in the formal economic sectors and freelancers. Economic agents in the labour market make decisions in order to optimize their own profit. The consumer of goods and services offers his skills and abilities to perform certain types of work (labour market supply), and the manufacturer has the necessary factors of production (including labour), pays a certain price, which shapes demand in the labour market. When the aggregate labour supply of individual consumer equals the demand in the labour market, provided that the values of the two parties are compared, balance is established (balancing condition). Depending on the period and market structure (monopsony or monopoly), the balancing conditions and form of establishment may vary. However, what is important is that labour market balance is difficult to achieve, and a state of constant imbalance is more natural.

While analysing the labour market in terms of the conjuncture, it should be noted that the entities responsible for demand show an advantage. This is not a distinguishing feature of the labour market, since in today's market economy there is a phenomenon known as the consumer market: the consumer (demand in the market) makes a choice of products offered by many suppliers (supply). Therefore, balance in such a market requires adjustment, mainly of the structure and dynamics of supply. In turn, the most important determinants of the labour market are the factors that influence it: wages and salaries, the number of people with certain qualifications, the benefits of informal employment, and the non-economic determinants of economic activity. In addition, labour market policy measures such as size and duration of unemployment assistance provided may be factors influencing the supply [4, p. 59].

Among the instruments that influence the supply in the labour market, special attention is paid to those measures that cause an increase in the quantity and quality of labour. This leads to a fuller use of the country's resources, a reduction of unemployment rate and an increase in employment. Reducing the mismatch between supply and demand in the labour market can encourage population to acquire higher qualifications, engage 
in self-education, which results in the support and implementation by the state of the concept of lifelong learning. The desired result of such activity is to increase the number of economically active high-skilled population, which is a valuable asset in the competitive labour market today. Note that the factors affecting aggregate and vacant demand are wages and labour productivity related to technological progress and indirect demand for products resulting from the labour provided [5, p. 84].

Based on the above, we formulated the hypothesis of this study: the balance of the labour market in the context of migration intensification can be achieved by the levelling pay disparities in the donor country and the host country, as well as creating an adequate number of high-paying vacancies.

Analysis of recent research. Employment issues, increase of unemployment, regulation of the labour market in the period of increased migration processes are accompanied by increased scientific activity. Research on this issue does not have a clear construction of mechanisms for ensuring balance in the labour market. Scholars such as P. Beer and T. Schils have taken a liberal approach to this problem [6]. A. Downes emphasizes that active intervention in the process of balancing supply and demand is justified only in lowcompetitive labour markets [7]. V. Druzhynina indicates the need for a priority principle of balancing regional and local labour markets. In her opinion, the balance in the labour market most influences the efficiency and productivity of employees [8]. J. Seitkhozhina recognizes the importance of balance in a time when there is significant growth in the labour market and pays particular attention to balancing in terms of gender and age equality rather than professional qualification [9].

Emigration reduces the supply of labour in the labour market, forecasting the volume and structure of migration flows requires understanding the factors that influence the formation of migrants' intentions. E. Elbadawy, based on an analysis of the determinants of youth migration intentions, found that unemployment is not an important factor stimulating emigration [10]. Most young people intend to migrate and are willing to do work that is not in line with their skills and specialization. This means that even skilled emigrants will initially perform low-paid and low-skilled jobs. A. David and A. Marouani cite the results of years of research into the labour market of emigrants, which show that more than half of all emigrants are unemployed [11], and argue that the sociodemographic adaptation of migrants affects the level of labour market balance both in host country and in donor country [12]. In particular, A. David and A. Lenoel assessed the impact of women's labour migration on structural changes and socioeconomic effect on regional labour markets [13].

Scientific approaches to the impact of migration on the labour market are conventionally divided into two categories: modelling based and effects research [14, 16]. Studies of migration effects based on the relationship between wage or employment variations and fluctuations in migration stocks or flows make it possible to identify migration risks and other current or potential changes in migration patterns. A small part of the studies on the impact of population migration on the labour market with a focus on balancing is based on empirical methods of cognition, and the results obtained are high estimates based on a comprehensive analysis of a large number of indicators in many countries [17]. Particularly noteworthy is the approach offered by L. Chernobay, V.Adamyk and S.Malibroda, which is based on modelling the interaction of international migration and the economy of the country hosting the migrants and providing them with certain opportunities, as well as the SNA-2008 principle applied for modelling [18].

In the context of deepening globalization processes, changes in labour supply are the causes of labour price transformations in the short term. Using a simulation approach, G.Borjas confirms the impact of emigration and immigration on regional and national labour markets [14]. Studies by B. Elsner [20], S. P. Kerr and V. Kerr [21], also conducted by the simulation method, and revealed a significant impact of emigration on wages. In broad terms, these results are consistent with the long-term impact of migration on socio-economic indicators, as evidenced by labour market theory. Their research focused on analysing the age 


\section{S. Lykholat, O. Mulska, N. Rozhko}

qualification of potential migrants, the impact of unemployment and employment on migration in the light of balancing supply and demand.

D. Card's research is focused on building an economic-mathematical model of the impact of emigration on indicators of regional labour markets. The researcher examined the migration effects in the focus of changes in wages and employment [15]. In addition, based on econometric approach for analysing the conditions of balancing the labour market, taking into account the consequences of migration, A. Glitz in his studies considered the massive international migration flows, which are mainly caused by socioeconomic factors for a limited period of time [19].

Some studies in this area [22, 23] focus on identifying the causes of labour market imbalance. In particular, it has been found that changes in the level of remuneration require labour demand to be corrected. If adjustment is made through labour supply, as a result, emigration only exacerbates the negative effects of unemployment in the host country and does not act as a regulatory mechanism.

\section{Methodology of research}

The study of the labour market in terms of intensification of migration processes was carried out with the method of system dynamics. The authors used Ex-Post analysis to establish the relationship of cause and effect, including feedback, between population migration and the level of labour market balancing. Using this method makes it possible to compare several labour market imbalances, taking into account a number of dimensions (wage rates, unemployment and employment rates, external migration volumes, etc.) over a long-term period in the country of emigration and immigration at the same time.

The mathematical apparatus of econometric analysis was applied to confirm the author's hypothesis, in particular such methods as multiple correlation analysis, regression analysis, multiplefactor analysis of variance, and Granger causality. The dependence of the level of labour market balancing (result attribute) on socio-economic factors has been identified using a multiple regression model constructed with the method of the least squares with instrumental variables
(2SLS). Such research tools allow considering the mutual causality between the studied variables. All values of the factors and the result attribute are reduced to a homogeneous series (standardized) and "cleared" from seasonality in order to get high estimates of the reliability of the obtained results. The constructed model helps to establish how any changes in socio-economic factors can lead to transformations in the labour market.

The adequacy of the econometric model was verified using the coefficients of reliability. The adjusted value of the coefficient of determination $\left(\operatorname{adj} . \mathrm{R}^{2}\right)$ is 0.98729 ; the coefficients of the DurbinWatson's (DW) statistics are within acceptable limits (about 2), without detecting autocorrelations of residuals.

Granger causality examines the relationship between socio-economic factors that determine the greatest impact on aggregate demand and aggregate supply in the labour market, external emigration of the population, determine the conditions of imbalances and the possibility of offsetting the imbalance of regional and national labour markets. The results of the analysis allow us to confirm the hypothesis about the mutual influence of the level of balancing of the labour market, where the aggregate supply is adjusted for the emigration of the population, and socio-economic factors, in particular the level of remuneration in the country of expulsion and acceptance of labour.

\section{The main results of the research Aggregate supply and demand in the labour market of Ukraine.}

In Ukraine, there is a tendency to reduce the number of employed population. For the period of 2010-2016, there was a gradual decrease of economically active population in conditions of increased external migration of the population, due to higher level of remuneration and social protection in the labour market abroad, as well as the military and political situation in Ukraine. Thus, the number of employed population aged 15-70 in the first half of 2017, compared with the first half of 2016, decreased by 118.4 thousand people (or $0.7 \%$ ) and amounted to 16.1 million, which includes 15.4 million people of working age. The employment rate of the population aged 15-70 has decreased from $56.2 \%$ to $56.0 \%$ during this period and the population of working age has increased from $64.0 \%$ to $64.2 \%$. 


\section{Labour market of Ukraine in the conditions of intensification of migration population processes}

The highest level of this indicator was observed among persons aged 30-49, and the lowest - among young people aged 15-24 and individuals aged 60-70. The employment reductions in 2017, compared to the corresponding period of the previous year, occurred among the population aged 25-49 and 60-70. The growth of this indicator was observed among persons aged 15-24 (by $1.4 \mathrm{pp)}$ ) and 50-59 (by $0.8 \mathrm{pp}$ ).

The number of unemployed (according to the ILO methodology) aged 15-70 in the first half of 2017, compared to the corresponding period of 2016, increased by 18.2 thousand people (or $1.1 \%$ ) and amounted to 1.7 million people. Among the unemployed, two thirds were urban dwellers (1.1 million people), the rest were rural residents. The increase in the number of unemployed people aged 15-70 was at the expense of persons of working age (by 19.2 thousand people or by $1.1 \%)$. Of the total number of unemployed, 1.4 million people $(81.7 \%)$ had previously worked, while the remaining 0.3 million had been looking for a job for the first time and had no work experience. The latter were dominated by young people who had not been employed after graduation. In particular, among those unemployed in the first half of 2017, the share of persons, aged 15-24 was $76.5 \%$, and in the age group of 25-29, this share was $21.8 \%$. More than two-thirds of the unemployed were looking for a job on their own $(69.1 \%)$ and the rest sought assistance from the State Employment Service. This situation is connected with the closure of a large number of industrial enterprises due to annexation of the Autonomous Republic of Crimea and military actions in Donetsk and Luhansk regions. The problem of internal migration of the population is also a pressing issue, which puts an additional burden on the labour market of certain regions in Ukraine.

According to the State Statistics Service of Ukraine, the number of vacancies declared by employers amounted to 66.5 thousand at the end of June 2017, which is $63.0 \%$ more than at the end of June 2016. One in four of the total vacancies was in the manufacturing industry, one in six was in the wholesale and retail trade; repair of motor vehicles and motorcycles, one in ten in transport, warehousing, postal and courier services.

The structural disparity between the demand for labour and its supply is a factor that limits both the employment opportunities of the unemployed and the satisfaction of employers' needs in workers.

The workload of registered unemployed for 10 vacancies in the whole country has decreased from 95 persons at the end of June 2016 to 50 persons at the end of June 2017.

The worsening of the relation between the labour supply and demand for it occurred in all groups of professions, while the most acute is the situation in the professions and specialties that do not require a high level of professional training and qualification of employees. Thus, 12 technicians applied for one job vacancy, 13 persons for trade and services, 14 persons for the simplest professions without special training, and 53 persons for agriculture and forestry, fish farming and fishing. By comparison, among the skilled workers and specialists, there were six applicants for one vacancy, and there were five applicants among professionals. Individual professions and specialties exacerbate structural discrepancies between the demand for labour and its supply. The most urgent problem is the imbalance in the qualification level, since a large part of unemployed citizens do not suit employers because of special requirements for the level of qualification and work experience (conclusions are made on the basis of data [24]).

It should be emphasized that there is a quantitative imbalance in the labour market of Ukraine, which is exacerbated by the low quality characteristics of a large number of vacancies, in particular the low level of wages. Among the vacancies announced by employers in 2016, over $30 \%$ offered wages that was at the minimum subsistence level, and only $8 \%$ of the vacancies offered wages above the average. At the same time, low wages are offered to highly qualified representatives of the working professions, as well as specialists in the fields of medicine, education, software, economics, jurisprudence, etc. [5, p. 61-62].

Based on the analysis of aggregate demand and supply for the years 2003-2017, it is possible to estimate the level of its balance ${ }^{1}$. Studies have shown that there is no balance in the labour market in Ukraine, since the value of the level of balance in the period 2003-2017 has fluctuated within

${ }^{1}$ The level of balancing was defined as the ratio of aggregate demand (occupied and vacant jobs) to aggregate supply (economically active population). 
90.77-97.56\%. Under such conditions, part of the economically active population is unable to find a job, and the unemployment rate is quite high. With the assistance of the State Employment Service, 232.4 thousand people were employed in the first half of 2017, and 236.2 thousand in the first half of 2016. Of the registered unemployed persons during the period, $43.9 \%$ women were employed and $34.8 \%$ were young people under 35 . During the first half of 2017 , more than two-thirds $(70.3 \%)$ of the registered unemployed were hired by agricultural, forestry and fishery enterprises, processing industry, as well as wholesale and retail trade; repair of motor vehicles and motorcycles. The share of employed persons increased by 3.0 percentage points compared to the first half of 2016 and in the first half of 2017, it accounted for $30.2 \%$ of citizens who were unemployed in the State Employment Service [24].

Ex-Post analysis, based on a comparison of the average wage (USD / h) and the volume of external migration (thousand people) in the longterm period, helped to demonstrate the situation on the labour market in Ukraine (Fig. 1). It should be added that the presented results support the conclusion that in periods of wages reduction in the donor country, migration volumes are increasing, but the balance of the labour market is not observed.

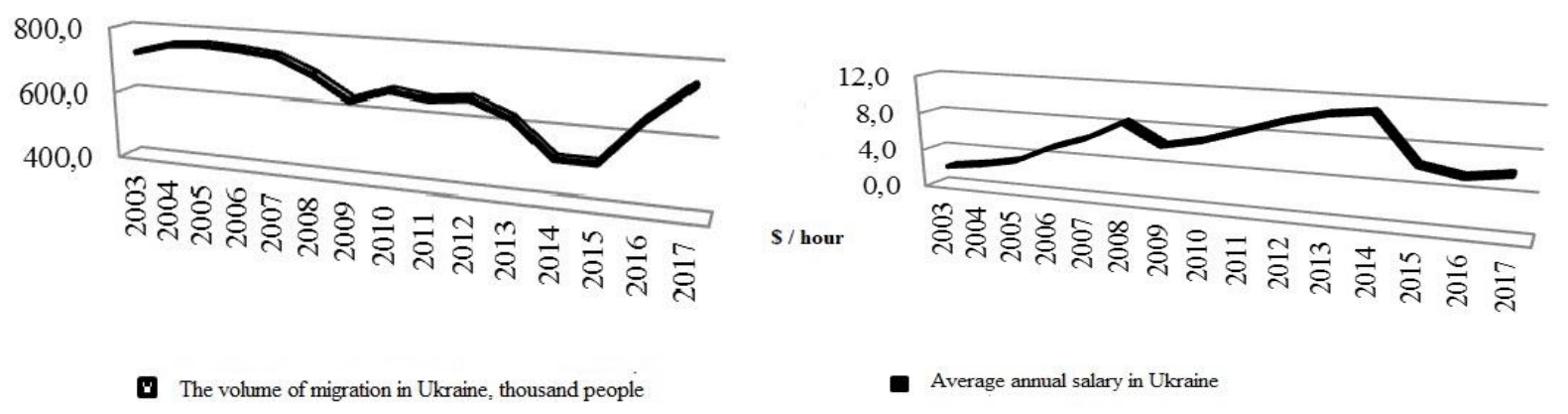

Fig. 1. Results of Ex-Post analysis of the labour market in Ukraine, 2003-2017

Formed by the author on the basis of official statistics of Ukraine [24]

\section{Analysis of the impact of migration on the level of labour market balancing in Ukraine.}

The results of the study of aggregate demand and supply in the Ukrainian labour market make it possible to calculate a labour market balancing index that would take into account external migration volumes (Fig. 2). Thus, due to the large number of migrants, the volume of aggregate supply on the market is decreasing, so, theoretically, the level of balancing should increase. However, the results obtained are the opposite. Only in the period of 2010-2011 the aggregate demand in the labour market was much higher than supply. This is explained by the stable socio-economic situation in the country, the increase in GRPs per person, the increase in average wages and social benefits. During the period of economic and political instability in Ukraine, migration activity of the population is increasing, but the balance in the labour market is not observed. To understand the causes of this situation, it is necessary to conduct a factor analysis of the impact on the level of labour market balance that considers the migration of the population.

Aggregate labour market supply is influenced by factors related to the characteristics of the region or country as a whole, the social structure of the population, demographic, migration, educational and financial components. Factors influencing aggregate demand are political, economic, innovation, investment, social and environmental factors. With the help of Granger causality, the relationship between labour market factors and conditions, namely aggregate supply and demand, were elaborated. The results of the analysis show that all factors that are closely related to the level of balancing have 
Labour market of Ukraine in the conditions of intensification of migration population processes

a function of direct dependence. The results of the study are presented in Table 1 .

Based on the empirical results, it can be concluded that the share of employed population aged 15-70 influences the level of balance (this is observed in two lags with a statistical significance of $10 \%)$. In addition, the level of balance affects the proportion of employed population aged 15-70 (with different statistical significance at the level of $5-10 \%)$. This is due to the fact that the employed population forms an aggregate supply, which basically determines the conditions for balancing the labour market.

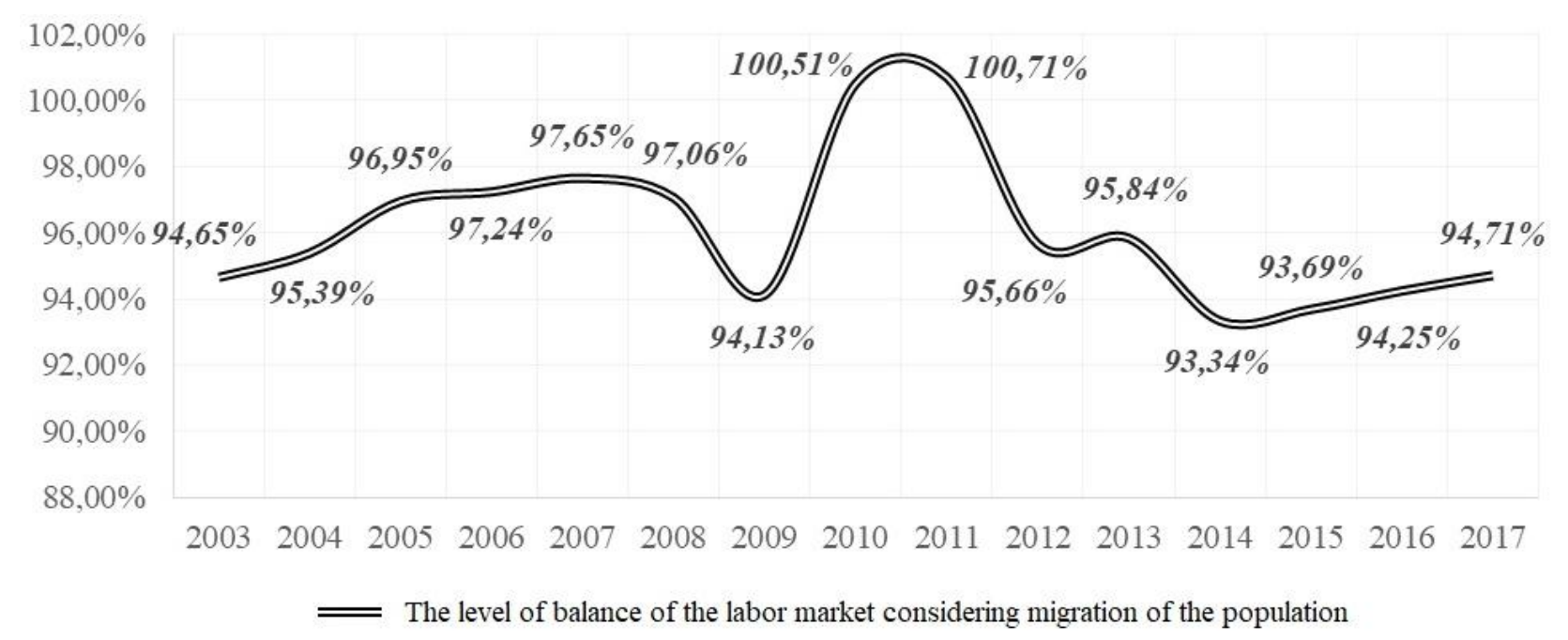

Fig. 2. Labour market of Ukraine considering migration of the population, 2003-2017

It is based on the author's calculations

Table 1

Influence of socio-economic indicators and the level of balance of the labour market (taking into account migration of population) (according to Granger causality)

\begin{tabular}{|c|c|c|c|}
\hline \multirow{2}{*}{ Impact hypotheses } & \multicolumn{3}{|c|}{ Lags } \\
\hline & 1 & 2 & 3 \\
\hline \multirow{2}{*}{ EMPL $_{t}$ on BALANCE $_{t}$} & 3.458 & 5.303 & 2.180 \\
\hline & $(0.096 *)$ & $\left(0.058^{*}\right)$ & $(0.453)$ \\
\hline \multirow{2}{*}{$B A L A N C E_{t}$ on $E M P L_{t}$} & 3.648 & 9.754 & 10.79 \\
\hline & $(0.089 *)$ & $(0.019 * *)$ & $(0.219)$ \\
\hline \multirow{2}{*}{ BALANCE $_{\mathrm{t}}$ on $\mathrm{VACDEM}_{\mathrm{t}}$} & 0.301 & 0.466 & 3.052 \\
\hline & $(0.594)$ & $(0.644)$ & $(0.131)$ \\
\hline \multirow{2}{*}{$V A C D E M_{t}$ on $B A L A N C E_{t}$} & 1.786 & 0.900 & 1.641 \\
\hline & $(0.208)$ & $(0.444)$ & $(0.293)$ \\
\hline \multirow{2}{*}{ BALANCE $_{t}$ on $\mathrm{UNEMPL}_{\mathrm{t}}$} & 0.327 & 1.289 & 1.492 \\
\hline & $(0.579)$ & $(0.327)$ & $(0.324)$ \\
\hline \multirow{2}{*}{$U N E M P L_{t}$ on $B A L A N C E_{t}$} & 3.208 & 3.244 & 1.956 \\
\hline & $\left(0.100^{*}\right)$ & $(0.093 *)$ & $(0.239)$ \\
\hline
\end{tabular}

Note: annual data are used for the analysis, where BALANCEt is a level of balance; EMPLt is share of employed population aged 15-70; VACDEMt - vacancy demand; UNEMPLt-unemployment rate of all population aged 15-70.

It is submitted according to the author's calculations 


\section{S. Lykholat, O. Mulska, N. Rozhko}

The lack of a significant effect of the level of balance on vacant demand is also noticeable. The level of balance does not have a significant impact on the unemployment rate (population aged 1570), while the unemployment rate affects the balance (in two lags with different statistical significance at the level of $10 \%$ ). This is primarily because unemployed people are potential migrants under the current conditions; they reduce the aggregate supply, but at the same time increase the imbalance in the labour market. As the average number of full-time employees grows, the balance index increases, and a decrease in the workload per vacancy causes a decrease in the level of balance. Thus, it can be argued that the current supply in the labour market will always cause an imbalance between aggregate demand and supply. Such conclusions can be drawn based on the results obtained by econometric modelling (1).

$$
\begin{aligned}
& B A L_{t}=-0.942-0.979 \text { BAL }_{t-1}+0.047 \text { AVER }_{t} \quad-0.009 \text { LOAD }_{t}-0.029 \text { RECEP }_{t}-0.049 \text { UNEMPL }_{t}-0.027 \text { WAGE }_{t}
\end{aligned}
$$

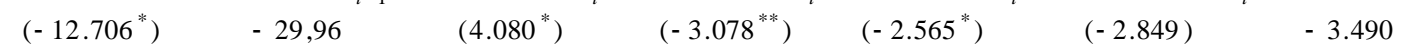

$$
\begin{aligned}
& \text { adj. } R^{2}=0.98 \quad D W-1.9
\end{aligned}
$$

Reduced employee acceptance limits the balancing index, reducing unemployment and wages does not increase the balance index. Yes, there is such a situation that as the average number of full-time employees increases, the balance index will increase by $0.47 \%$, and with the decrease of the load for one vacancy by $1 \%$, it will decrease by $0.009 \%$. Thus, if the level of employee reception is reduced by $1 \%$, the level of balancing will decrease by $0.029 \%$; as unemployment and wages decrease by $1 \%$, the balance index will decrease by $0.48 \%$ and $0.027 \%$ respectively.

The increase in aggregate demand reflects the prospective development of the country's economy and, accordingly, the improvement of the structure of jobs or the increase in their number. Such changes will be at the expense of sustainable development of enterprises that create new jobs, increase productivity, overcome technological backlogs and create decent working conditions by increasing direct investment in the Ukrainian economy. The increase in aggregate supply will be driven by improved demographics, as well as minimizing the negative effects of migration, an increase in average wages and a reduction in the turnover of highly skilled workers.

It should be emphasized that the high level of labour migration of both workers and highly skilled workers has a significant impact on the labour market in the country. Therefore, its regulation becomes a decisive factor for balancing the labour market and, consequently, the socioeconomic development of Ukraine.

\section{Conclusions}

The conducted research shows that labour emigration is sensitive to socio-economic conditions in the country. As a rule, previous studies have used factor analysis methodology to identify the impact of socio-economic factors on the labour market situation of the donor country or the host country. The author's approach to the study of the level of labour market balancing in terms of migration intensification, in contrast to previous studies, focuses on identifying the influence of dominant socio-economic factors of employment on the level of labour market balancing, which is defined in the form of an index, where the aggregate supply is adjusted for emigration volumes. Based on the presented model of dependence of socio-economic factors and the level of balancing of the labour market, taking into account the migration of the population, the authors confirmed the hypothesis that employment and unemployment, as well as the level of remuneration in the donor and host countries exert a dominant influence on the total labour supply in the regional labour market, shape new conditions of flexibility of the open labour market of Ukraine.

It has been proven that such a labour market balancing tool as an increase in wages in the labour donor country does not effectively balance aggregate demand and aggregate supply in the labour market. The intensity of labour migration is determined by the widening wage gap in the countries of displacement and 


\section{Labour market of Ukraine in the conditions of intensification of migration population processes}

attraction of migrants, which is why it is a fundamental factor in reducing the labour supply in the regional labour market.

The study of wage levels by systematic dynamics and Ex-post analysis has confirmed that the decrease in the economically active population and the unemployment rate are the factors that stimulate wage increases and eliminate imbalances in the labour market only in the long-term period. On the other hand, increasing emigration helps balance regional labour markets in the short term, but only in the low skilled and low paid segment.

\section{References}

1. Fedunchyk L. H. (2016) Labour market in Ukraine: problems and directions of their solution. Labour market and employment. No. 2. P. 31-34.

2. Sadova U., Semiv L. (2000). Regional labour markets: analysis and forecast. Lviv. 264 p.

3. Levytska O. O. Challenges and Perspectives for the Development of Human Resource Management and Labour Relations in the Information Society // Socio-economic problems of the modern period of Ukraine: [collection of scientific works] / NAS of Ukraine. Institute for Regional Studies; resp. editor V. S. Kravtsiv. Lviv, 2017. Edition 6(128). P. 99-102.

4. Ehrenberg R. G., Smith R. S. (2012). Modern Labour Economics. Theory and Public Policy. New York: Prentice Hall. 682 p.

5. Zoidze D. R. (2016). The modern labour market: the dismissal of hired workers as a factor of the structural mismatch between supply and demand. Problems of economy. No. 2. P. 59-65.

6. P. de Beer, T. Schils The labour market triangle. Employment Protection, Unemployment Compensation and Activation in Europe. Cheltenham: Edward Elgar, 2009. 238 p. URL: https://hdl.handle. net/11245/1.363581

7. Downes, Andrew S. (2009). Labour Market Aspects of the Global Economic Crisis. Paper presented at ILO Conference, April 1-2, Jamaica.

8. Druzhynina V. V. (2013). Principles of formation of the balance mechanism of the local labour market. Current problems of the economy. No. 4(142). P. 202-208.

9. Seitkhozhina J. A. (2014). Gender asymmetry at the labour market in the Republic of Kazakhstan. Current problems of the economy. No. 1. P. 368-375.
10. Asmaa Elbadawy. (2011). Migration Aspirations Among Young People In Egypt: Who Desires To Migrate? Working Paper Series, $N^{\circ} 619$, September 2011. URL: https://erf.org.eg/wp-content/ uploads/2014/08/619.pdf

11. Anda M. David, Mohamed Ali Marouani (2015). Migration and Employment Interactions in a Crisis Context: the Case of Tunisia. Economics of Transition, vol. 23(3), pp. 597-624. https://doi.org/ 10.1111/ecot.12074

12. Anda M. David (2015). Back to Square One: Socioeconomic Integration of Deported Migrants. International Migration Review. Vol. 51, Issue 1, 2017. https://doi.org/10.1111/imre.12208

13. Anda M. David, Audrey. Lenoel (2016). International emigration and the labour market outcomes of women staying behind: the case of Morocco, Papiers de Recherche AFD, $n^{\circ}$ 2016-23, Mai. URL: https://www.afd.fr/en/ressources internationalemigration-and-labour-market-outcomes-womenstaying-behind-case-morocco

14. George J. Borjas (2005). Native Internal Migration and the Labour Market Impact of Immigration. Human Resources Spring 2006 vol. XLI no. 2. pp. 221-258. DOI: 10.3368/jhr.XLI.2.221.

15. Card David (2009). Immigration and Inequality. American Economic Review, 99 (2), pp. 1-21. DOI: 10.1257/aer.99.2.1

16. Okkerse L. (2008). How to Measure Labour Market Effects of Immigration: a Review. Journal of Economic Surveys, Vol. 22, Issue 1, 2008, pp. 1-30. https://doi.org/10.1111/j.1467-6419.2007.00533.x

17. Ruge-Murcia F. (2012). Estimating nonlinear DSGE models by the simulated method of moments: With an application to business cycles. Journal of Economic Dynamics and Control, Vol. 36, Issue 6, June 2012, pp. 914-938. https://doi.org/10.1016/j.jedc.2012.01.008

18. Chernobay L., Adamyk V., Malibroda S. (2019). An approach to modelling the impact of international migration on the economy of receiving country. EEM. 2019; Volume 6, Number 1 : pp. 47-69. https://doi.org/10.23939/eem2019.01.047

19. Glitz A. The Labour Market Impact of Immigration: A Quasi-Experiment Exploiting Immigrant Location Rules in Germany. Journal of Labour Economics 30, no. 1 (January 2012). pp. 175-213. https://doi.org/ $10.1086 / 662143$

20. Elsner B. (2013). Emigration and wages: The EU enlargement experiment. Journal of International Economics. Vol. 91, Issue 1, September 2013, 


\section{S. Lykholat, O. Mulska, N. Rozhko}

pp. 154-163. https://doi.org/10.1016/j.jinteco. 2013.06.002

21. Sari Pekkala Kerr, William R. Kerr, 2011. Economic Impacts of Immigration: A Survey. Finnish Economic Papers, Finnish Economic Association, vol. 24(1), pp. 1-32. URL: https://www. nber.org/papers/w16736

22. Prachi Mishra (2007). Emigration and wages in source countries: Evidence from Mexico. Journal of Development Economics, Volume 82, Issue 1,
January 2007, pp. 180-199. https://doi.org/10.1016/ j.jdeveco.2005.09.002

23. Alfonso Miranda, Yu Zhu (2012). English Deficiency and the Native-Immigrant Wage Gap. Economics Letters. Volume 118, Issue 1, January 2013, Pp. 38-41. https://doi.org/10.1016/j. econlet.2012.09.007.

24. State Statistics Service of Ukraine. URL: http://www.ukrstat.gov.ua/ 